\title{
日㷌り内視鏡下鼻内手術
}

$\begin{array}{llll}\text { 石坂 } & \text { 成康・出島 } & \text { 健司・濱 } & \text { 雄光・宮崎 信 } \\ \text { 安田 } & \text { 繁伸・福島 } & \text { 一登・久 } & \text { 育男 }\end{array}$

\section{A Clinical Study of Day-Surgery in Endoscopic Sinus Surgery}

\author{
Shigeyasu Ishizaka, Kenji Dejima, Takemitsu Hama, Makoto Miyazaki, \\ Shigenobu Yasuda, Kazuto Fukushima and Yasuo Hisa \\ (Kyoto Prefectural University of Medicine)
}

\begin{abstract}
Day-surgery is expected to advance with the development of medical technology and social and economic demand. In this study, the charts of 55 cases (53 patients aged 11-81 y.o.) who underwent endoscopic sinus surgery (ESS) as day-surgery were analyzed retrospectively and questionnaires on the operation were performed. ESS was performed in 39 cases of chronic sinusitis, 9 cases of paranasal cyst, 3 cases of inverted papilloma and 2 other cases. The operative procedures were performed on the unilateral cavity in 47 cases, and on the bilateral cavity in 8 cases. In most patients only the unilateral maxillary and ethmoid sinuses were operated on. While bleeding volume was under $10 \mathrm{ml}$ in 49 cases, it was over $50 \mathrm{ml}$ in 3 cases. Although the average operation time was about 55 minutes, it took over 90 minutes in 5 cases. Because of post operative bleeding, prolonged management or reconsultation was needed on the operation day in 4 cases. Admission was necessary in 2 cases; one due to tinnitus and vertigo, and the other due to cerebrospinal fluid leak. According to the questionnaires, most of patients wanted a day-sugery because of their schedule, and they were mainly anxious about bleeding after returning home. From the findings of this study we suggest that the indications of day-surgery in ESS are 1. The patient is over 10 y.o. and has no severe past-history. 2. The patient lives near the hospital. 3. The diagnosis is unilateral sinusitis, or bilateral sinusitis that is mild on at least one side, or paranasal cyst for which an endonasal approach is required, or benign tumor without risk of excessive bleeding. The control of bleeding and the prevention of infection are the most important issues for the advance of ESS as day-surgery.
\end{abstract}

Key words : day-surgery, endoscopic sinus surgery, indication

\section{はじめに}

日帰り手術 (day-surgery) は医療技術の発達と社会的

・経済的要請から今後増加していくものと予想されるが, 耳鼻咽唉科は従来から日帰りでの局所麻酔下手術を多数 行ってきた診療科であり，こうした動向には関連が深 (、1) 3). 近年鼻科領域に怙いては鼻内副鼻腔手術が内視 鏡下に行われることが一般的となり, Caldwell-Lucの 手術などの経上買洞的手術に比べて侵襲は格段に軽减し
て扣り，すでに日帰り手術として施行している施設も少 なくないであろう。しかしその適応の決定には苦慮する こともあり，現状では広くコンセンサスが得られている とはい亲ない，そこで当科の最近の症例について検討し， 文献的考察を加えて適応拡大に向けた問題点を挙げてみ ることにする。 


\section{対象・方法}

対象は平成 8 年 6 月より平成11年 1 月までに当科で日 帰りで施行するべく計画された内視鏡下鼻内手術症例の べ55例，53名である．手術室で施行した症例のみを対象 とし，外来の診察台で行った小手術や処置は除外した。 手術は原則として全症例を同一術者が行ったが，一部症 例で麻醉処置・鼻茸切除・タンポンガーゼ挿入を他者が 分担した.

手術を日帰りで行うか入院の上で行らかの判断は患者 およびその家族と十分相談し，個々の症例で臨床症状や 社会的事情を考慮して決定された．基本的に両側に中等 症以上の病変が存在したり問題となるような合併症があ れば日帰り手術は適応外とした。

カルテ記載括よび手術記録により症例の性別，年齢， 対象疾患, 手術の操作範囲, 前投薬 - 麻酔薬, 出血量, 手術時間, 合併症の有無, 術中・術後の問題点を検討し た。また患者へのアンケートにより患者側からみた日帰 り手術の長所・短所についても検討した。

な怙，当科の日帰り内視鏡下鼻内手術に拈ける患者や 家族に対する指導や管理は以下のようなものである.手 術当日は家族が付さ添うことを原則とするが，困難な場 合には緊急連絡先を確認した上で友人・知人の付き添い でも可とする. 術後は十分な観察の後に帰宅させるが, 当日はできるだけ坐位や仰臥位で安静とし，飲水にてむ せないことを確認してから领食可とする．翌日からデス クワークなどの軽作業や通学は許可するが激しい運動は 不可であり，入浴はシャワーなどで軽めにさせる．当院 は大学附属病院であり毎日耳鼻咽喉科の当直医がいるた め緊急時に手術担当医が不在であればこの医師が対応す る. 通常は術後 3 日目が最初の再診日となり鼻内のタン ポンを抜去するが，その日は激しい運動と入浴を避けて もらう．その後の処置は比較的広い範囲を操作した場合 であれば術後 2 週間は週に 2 回行い, さらに週に 1 回,

2 週に 1 回と間隔を開けていくが，これは入院症例と同 様である.

\section{結果}

（1）性別・年齢：男性 30 名・女性23名で平均年齢は 44.6 歳, 最年少は11歳, 最年長は81歳であった。

（2）対象疾患(表 1)：慢性副鼻腔炎が39例でそのらち 7 例が再手術であった。副鼻腔豊胞が 9 例で流かは内翻 性乳頭腫 3 例，血管腫 1 例，蝶形骨洞の生検を行った扁
表 1 対象疾患

\begin{tabular}{lll}
\hline \hline 慢性副鼻腔炎 & 39 例 & （初回手術 32 例, 再手術 7 例） \\
副鼻腔囊胞 & 9 例 & （原発性 3 例, 術後性 6 例） \\
内翻性乳頭腫 & 3 例 & （初回手術 1 例, 再手術 2 例） \\
血管腫 & 1 例 & \\
扁平上皮癌 & 1 例 &
\end{tabular}

平上皮癌 1 例であった。

（3）操作範囲（表 2 ）：再手術例も少なくないため，篩 骨洞は前部・後部の区別をつけなかった．片側が47例， 両側が 8 例であり，片側例のなかでは上䫇洞・篩骨洞を 操作したものが17例と最多であった。これに前頭洞また は蝶形骨洞を加えた症例があわせて12例あり，沉副鼻腔 手術も 1 例あった. 両側例では両節骨洞操作例が 5 例で 中鼻道癒着やポリープ再発に対する再手術例が占めてい た.

（4）前投薬・麻酔 : 成人の入院症例では硫酸アトロピ ン・ヒドロキシジン・ペンタジシンを使用しているが， 日帰り症例では48例が硫酸アトロピン・ヒドロキシジン のみであり，そのうち31例ではヒドロキシジンは入院症 例の $1 / 2$ 量 (25 mg・筋注) としていた。麻酔は全例 $5 \%$ 塩酸コカインによる表面麻酔と $1 \%$ ％ドカインによる浸 潤麻醉を行った．蝶口蓋神経節ブロックは行っていない．

（5）術中出血量(図 1)：計測し得た限りでは55例中49 例が $10 \mathrm{ml}$ 以下と少なかった。 $50 \mathrm{ml}$ を越光る出血が あったのは 3 例で, 最多 $(100 \mathrm{ml})$ は特に合併症のない 慢性副鼻腔炎の片側・初回手術例であったが， ほかは内 翻性乳頭腫症例と扁平上皮癌生検例の各 $80 \mathrm{ml}$ であった。

\section{表 2 操作範囲}

\begin{tabular}{|c|c|c|c|c|}
\hline \multirow[t]{9}{*}{ 片側 } & \multirow[t]{9}{*}{ 47例 } & \multicolumn{3}{|c|}{ 鼻中隔のみ 1 例 } \\
\hline & & \multicolumn{3}{|c|}{ 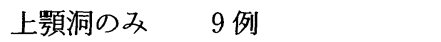 } \\
\hline & & \multirow{2}{*}{\multicolumn{3}{|c|}{$\begin{array}{l}\text { 笠骨洞のみ } \\
\text { 蝶形骨洞のみ }\end{array}$}} \\
\hline & & & 3 例 & \\
\hline & & \multicolumn{3}{|c|}{ 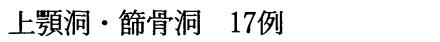 } \\
\hline & & \multicolumn{3}{|c|}{ 篩骨洞・前頭洞 1 例 } \\
\hline & & \multirow{2}{*}{\multicolumn{2}{|c|}{ 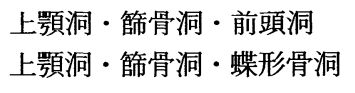 }} & 9 例 \\
\hline & & & & 3 例 \\
\hline & & \multicolumn{2}{|l|}{ 沉副鼻腔 1 例 } & \\
\hline \multirow[t]{3}{*}{ 両側 } & \multirow[t]{3}{*}{8 例 } & \multicolumn{3}{|l|}{ 両篩骨洞 5 例 } \\
\hline & & \multicolumn{3}{|c|}{ 両上顎洞・篩骨洞 2 例 } \\
\hline & & \multicolumn{3}{|c|}{ 両上顎洞・篩骨洞・蝶形骨洞 } \\
\hline
\end{tabular}




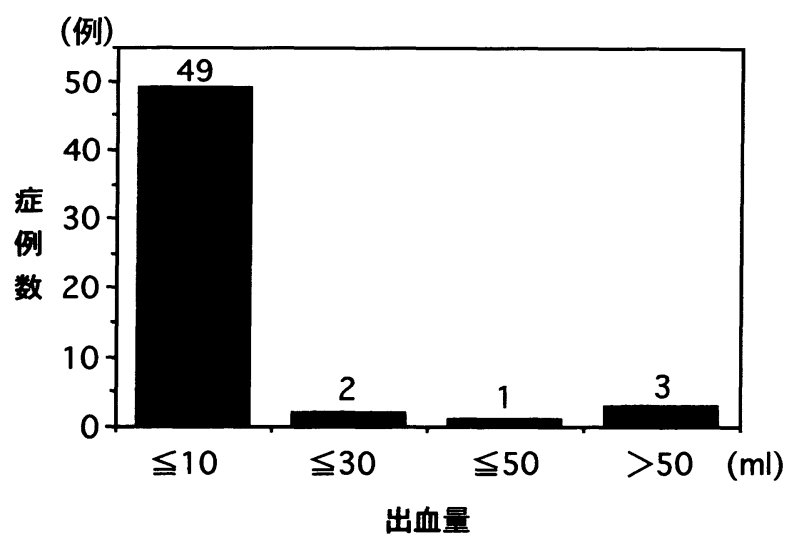

図 1 術中出血量

高血圧合併症例で出血量の有意な増加は認められなかっ た。

（6）手術時間(図 2)：全症例の平均手術時間は55分で, 片側例53分，両側例69分であった．90分を越えた症例が 5 例あり，与ち 3 例が再手術症例 (片側 1 例, 両側 2 例) で，ほかは最も出血の多かった症例と術中一過性の血圧 低下を生じた症例であった。

（7）術中・術後の問題点：出血に関するものが多く, 術中では咽頭への流血を嚥下・嘔吐した者が 1 例あった。 当科では術後 $1 \sim 2$ 時間の安静の後に止血を確認して帰 宅させているが，少量の出血が断続的にみられ 3 時間あ まり観察後に帰宅した症例が 2 例あり，いずれも高血圧 合併例であった.この 2 例とは別に手術当日出血のため に再診した症例が 2 例あったが，処置後帰宅した。また

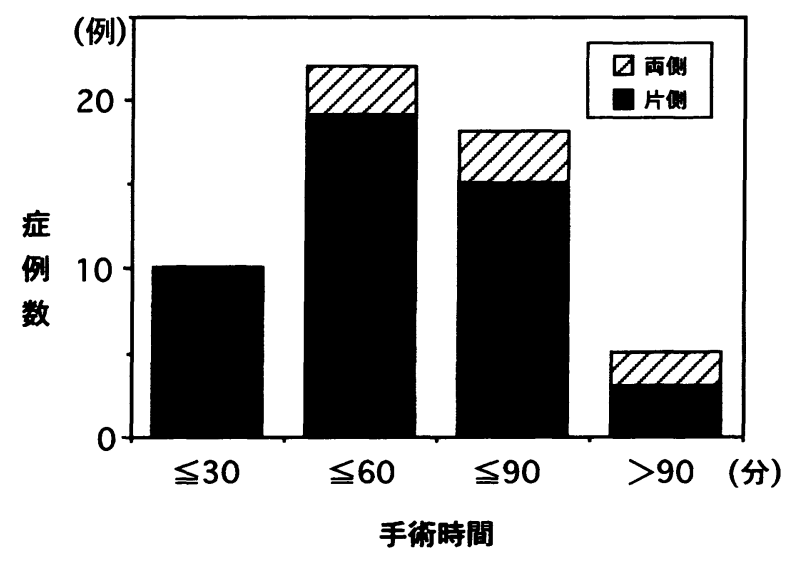

図 2 手術時間
鼻の手術の場合タンポン抜去時の出血の問題があるが， 今回の検討では全例べスキチン $\mathrm{F}^{\circledR}$ を使用して術後 3 日 目頃に抜去を行い, タンポンの再度挿入を必要とするよ うな出血はなかった。出血以外には手術直後にめまい. 耳鳴を訴えて観察入院した症例があったが，当日夜に眼 振は消失し翌日には症状も軽快して退院した。蝶形骨洞 の扁平上皮癌症例は CT や MRI などの画像検査では悪 性腫瘍を強く疑うものではなかったため日㷌りで生検を 行らことにしたが，閉鎖した自然口部を開空したと同時 に拍動性の出血を認めたため髄液瘻の疑いで緊急入院し た. 幸い保存的治療で気脳症・髄液瘦は数日で改善し, 扁平上皮癌の確定診断後に放射線治療や化学治療を行い 現在も腫瘍再発を認めずに外来で観察中である.

（8）患者アンケート（図 3 ）：患者53名中転居先不明の 2 名を除く51名にアンケートを送付し，31名から回答を 得た。手術前には25名(81\%)が日䚻り手術を希望してお り，主な理由は仕事・家庭・学校の都合など日程上の問 題であった．手術時間については $90 \%$ 以上が短かったあ るいは我慢できる程度と答觉, 長かったと回答した 3 名 の手術時間はそれぞれ80分，65分，60分であった. 帰宅 後は半数以上 $(18$ 名, $58 \%)$ が不安にかられて扣り, その 主な要因は出血(11名), 痛み ( 3 名)であった. 再び同じ 手術を受けると仮定した場合，10名が日帰り手術を，15 名が何かあれば緊急入院の対応も可能といら前提であれ ば日帰り手術を，5名が入院を希望した。

\section{考察}

日帰り手術の適応について森山11) は手術時間の短いこ とも含めて minimally invasive であることを必須の条件 とし，一般的条件として次の 6 項目を挙げている.

1. 術後の出血の少ないもの. また出血しても容易に 止血可能なもの.

2. 術後の気道狭窄や閉塞の恐れのないもの. 術後の 気管内への血液の流入のないこと.

3. 術後に激しい疼痛のないもの(坐薬や内服の鎮痛 剂でュントロール可能なもの).

4. 術後に経口摂取が可能であること.

5 . 術後の感染の危険性の少ないこと. また感染して も重篤な合併症に至らないもの(通常の経口の抗生剂投 与で十分に感染が防げるもの).

6. 術後にめまい(嘔吐)などがなく独歩できるもの. 内視鏡下鼻内手術の出血は全般的に少なく, Lazar 


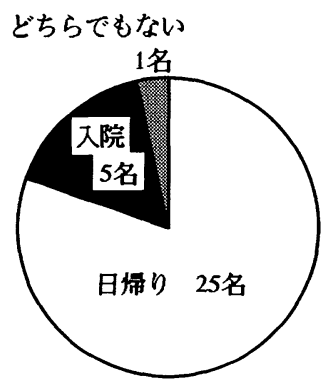

Q1. 手術前の希㤠は？

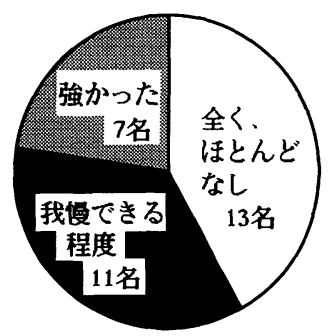

Q4. 㷌宅後の不安は？

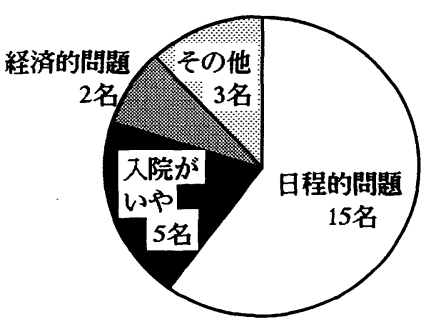

Q2. 日师り手術希哇の理由は？

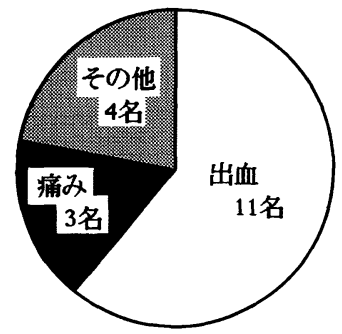

Q5. 不安の主な要因は？

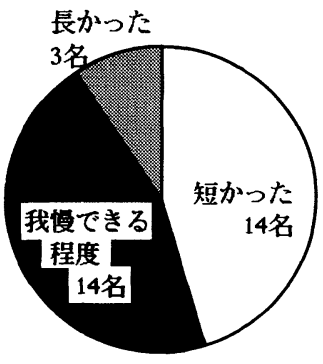

Q3. 手術時間は？

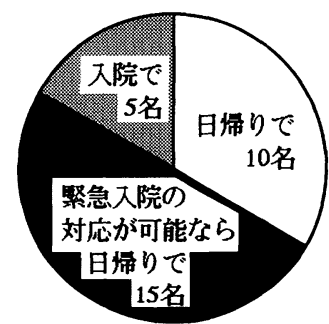

Q6. 再び手術を受ける場合は？

図 3 アンケート結果

ら4)は両側の functional endonasal sinus surgery を施行 した成人 513 症例の平均術中出血量を $45 \mathrm{ml}(30 \sim 100 \mathrm{ml})$ と報告している，一般的に術後出血も少ないが，咽頭へ の流血が続くようであれば自宅での対処には限界がある. 術後タンポンの圧迫による痛みや頭重感を訴えることが あるが，通常は坐薬などでュントロール可能であり，ま た数時間後には経口摄取もできる。当科では日帰り症例 に手術終了時の鼻内タンポン挿入中から抗生物質を点滴 投与しているが，経口剤のみでもまず問題はない，しか しわずかながら㭪道膜炎や toxic shock syndrome をはじ め重篤な合併症を生じる可能性はあり5)6)，培養検査を 行って括くとともに術前から膿性鼻漏の減少飞努め, 術 後はバイタル・サインに注意する必要がある. 今回の検 討症例のなかには術後めまい・耹を姓じて 1 日観察入 院した症例があったが，これは経耳管的に麻醉薬が中耳 に流入したためと考えられる. しかし最近数年の入院症 例を含めても同様のケースはなく，きわめてまれである. 以上から日䚻りでの内視鏡下鼻内手術は前述した森山の 示す条件の多くを満たすが，出血の制御と重大な感染症 の防止が適応を決定する上で重要な要因と思われる。

適応についてもら少し細かく考えてみると，年齢につ
いてはわれわれは10歳以上を一応の目安としているが， 術者や看護婦の指示を聞き分けてくれさ交すればさらに 年少でも可能である. 高齢者に打いては従来の副鼻腔根 本手術であればその侵襲の大きさから回避していた症例 でも内視鏡下手術の導入により手術治療を選択しやすく なったが，日㷌りで行らかどうかは合併症次第であろ 5.

対象疾患は主に慢性副鼻腔炎・副鼻腔囊胞の一部・良 性腫瘍の一部となるが，事前に出血の多いことが予想さ れる場合や鼻内以外のアプローチを併用する可能性があ れば数日の入院を考慮せざるを得ない，蝶形骨洞内に及 ぶ手術でも内視鏡の発達した現在では操作の確実性が格 段に向上し，また上頱洞や前頭洞のように鼻内以外から のアプローチを併用することが注とんどないため日帰り で計画することも可能となったが，出血や唱膜への影響 が懸念される症例はできれば 1 日の観察入院とするのが 安全である。また両側ともに広範囲を操作した場合両側 鼻内への多数のタンポン挿入は帰宅後の苦痛も大きく, またタンポン抜去後数日間は浮腫や痂皮付着が強いため に頻回の局所処置が必要となることから，少なくとも一 側が軽症のものを選択すべきであろう．同様の理由から 
鼻中隔矯正術の併施が必要な症例も入院が望ましい.

患者にとって手術が長くてつらいと感じるのは単に手 術時間だけでなく痛みや同一体位の維持・不安などさま ざまな要因が関与すると思われるが，アンケートで手術 が長かったと答えた 3 症例の手術時間はいずれも 60 分以 上であった. 術後数時間の観察の後に帰宅することを前 提とすれば抗不安剂の使用も最小限にとどめて, 手術時 間はできれば 60 分以内，長くとも90分以内としたい.こ れを基準にしても操作範囲については片側であれば汎副 鼻腔手術まで，両側でも篩骨洞・上顎洞を中心に前頭洞 ・蝶形骨洞を適宜加兄る程度であれば十分可能である.

日㷌り手術に限らないが術中の出血は手術時間に影響 を与光る大きな要因であり, 今後も術前・術中の管理と 手術手技や器具の工夫が必要である. 特に高血圧症合併 例では出血の制御に気を配ることになるが，今回の検討 では術中の出血はさほど多くないものの術後体動にとも なって出血をさたす例がみられ, やはり日㷌り手術の適 応については慎重を要する，㷌宅させるまでの観察や管 理に十分な時間がとれるよう留意すべきであり，自宅が 遠方の場合は最初から入院を選択したほらが無難であろ 5. 全例が近医の協力を得られればよいのだが，残念な がら耳鼻咽喉科医が24時間対応でさる医療機関は限られ ているのが現状であり, 緊急時には30分程度で来院可能 であることが望ましい.

以上の検討結果に基づいて表 3 に現在のわれわれの施 設に括ける日帰り内視鏡下鼻内手術の適応を示す．各施 設で手術室や回復室などの設備，co-medicalを含めた スタッフの規模や経験が違らことから出血などの緊急時 の対応も異なり, 日帰り手術の適応も当然違ったものに なるであろう．Brown ら7 は day-surgery として計画さ れた functional endoscopic sinus surgery (FESS) 症例 の $22 \%$ が入院が必要となり, その理由は出血や覚醒不十 分 (多くが全麻), 疼痛であったとしている. Smith ら ${ }^{8)}$ の報告ではFESS 200例のうち outpatient surgery が

\section{表 3 当科に持ける適応}

- 10 歳以上

・重篤な合併症がない

・30分程度で来院可能な範囲に居住

・片側性または両側性でも一方が軽症の副鼻腔炎 鼻内からのみで十分開放可能な副鼻腔囊胞 出血の少ない一部の良性腫瘍
84.5\%を占め, overnight stay と prolonged stay が若干 あったものの平均在院日数は 1 日未満であった. 今回の われわれの症例にも観察入院や当日再診を要したものが あったが，せいぜい一晚の入院までで，多くの危険性と 患者の不安を回避でさたものと推察される. 日帰り内視 鏡下鼻内手術の適応はさらに拡大可能と思われるが，そ のためには将来的に 1 日入院することまでを想定した (術後24時間以内に退院する) day-stay-surgery として施 設や体制を整備するのも一法であろら．いずれにしても 最も重要なことは, 個々の患者にとって本当に満足のい くものであったのかといら点を常にフィードバックしな がら day-surgery を安全に推進していくことであり，そ のためにも今回のよらな検討を重ねていく必要があると 考㝋る.

$$
\text { まとめ }
$$

1. 内視鏡下鼻内手術は日帰り手術のよい適応となり 得るがその拡大には出血の制御と重篤な感染症への対応 が重要な課題である.

2. 将来的には day-stay-surgery のシステムを整備す るなど患者の満足と安全性を備えた日㷌り手術を推進す ベきである。

本論文の要旨は第61回耳鼻咽喉科臨床学会(平成11年 6 月, 別府)に执いてロ演した.

\section{参考文献}

1 ）森山 寛：鼻の日㷌り手術. 耳鼻臨床 88 : 980 982, 1998.

2 ）神崎 化, 國弘幸伸: 耳鼻咽喉科に扣ける Day Surgery. 日医雑誌 $121: 1009 \sim 1012,1999$.

3 ) 黄川田徹, 秋田茂樹, 加藤洋治 : 耳鼻咽喉科と Day surgery. JOHNS 8 : 1475 1479, 1992.

4) Lazar RH, Younis RT and Long TE : Functional endonasal sinus surgery in adults and children. Laryngoscope $103: 1 \sim 5,1993$.

5 ) 深見雅也 : ESS の手術後合併症. 内視鏡的副鼻腔手術 (大 西俊郎, 小澤 仁, 笠原行喜, 他編). 143 146頁, メジ カルビュー社, 東京, 1995.

6 ）西原信成, 湯本英二：慢性副鼻腔炎術後の toxic shock syndrome 例. 耳鼻臨床 $88:$ 1599 1603, 1998.

7 ) Brown PM, Fowler S, Ryan R, et al : ENT day surgery in England and Wales; an audit by the Royal College of Surgeons (Eng.) Comparative Audit Service. J Laryngol Otol 112 : 161 165, 1998. 
8 ) Smith LF and Brindley PC : Indications, evaluation, complications, and results of functional endoscopic sinus surgery in 200 patients. Otolaryngol Head Neck Surg 108 : $688 \sim 696,1993$.
/原稿受付 : 平成 12 年11月 9 日

原稿採択 : 平成12年12月13日

別刷請求先: 石坂成康

干602-8566 京都市上京区河原町通広小路上る 梶井町 465

京都府立医科大学耳鼻咽喉科学教室 